\title{
Inheritance and Allelic Relationship Among Downy Mildew Resistance Genes in Pearl Millet
}

Chandramani Raj, Professor Jaya Shankar Telangana State Agricultural University (PJTSAU), Rajendranagar, Hyderabad 500030, Telangana, India; and International Crops Research Institute for the Semi-Arid Tropics (ICRISAT), Patancheru, Hyderabad 502324, Telangana, India; Rajan Sharma, ${ }^{\dagger}$ ICRISAT, Patancheru, India; B. Pushpavathi, PJTSAU, Rajendranagar, India; S. K. Gupta, ICRISAT, Patancheru, India; and K. Radhika, PJTSAU, Rajendranagar, India

\begin{abstract}
Pearl millet downy mildew (DM), caused by Sclerospora graminicola, is of serious economic concern to pearl millet farmers in the major cropgrowing areas of the world. To study the inheritance and allelic relationship among genes governing resistance to this disease, three DM-resistant pearl millet lines (834B, IP 18294-P1, and IP 18298-P1) and one susceptible line (81B) were selected on the basis of disease reaction under greenhouse conditions against two isolates of $S$. graminicola (Sg 526-1 and Sg 542-1). Three resistant parents were crossed with the susceptible parent to generate $\mathrm{F}_{1}, \mathrm{~F}_{2}$, and backcross $\mathrm{BC}_{1} \mathrm{P}_{1}$ (susceptible parent $\times \mathrm{F}_{1}$ ) and $\mathrm{BC}_{1} \mathrm{P}_{2}$ (resistant parent $\times F_{1}$ ) generations for inheritance study. To carry out a test for allelism, the three resistant parents were crossed with each other to generate $F_{1}$

and $\mathrm{F}_{2}$ generations. The different generations of these crosses were screened for disease reaction against two isolates ( $\mathrm{Sg} 526-1$ and $\mathrm{Sg} 542-$ 1) by artificial inoculation under greenhouse conditions. The segregation pattern of resistance in the $\mathrm{F}_{2}$ and corresponding backcross generations revealed that resistance to DM is controlled by a single dominant gene in 834B and IP 18294-P1 and by two dominant genes in IP 18298-P1. A test for allelism inferred that a single dominant gene for resistance in 834B is nonallelic to that which governs resistance in IP 18294-1, whereas one of the two dominant genes for DM resistance in IP 18298-P1 against the test isolates is allelic to the gene for DM resistance in $834 \mathrm{~B}$ and a second gene is allelic to the resistance gene present in IP 18294-P1.
\end{abstract}

Pearl millet downy mildew (DM) or green ear disease, caused by the oomycete Sclerospora graminicola (Sacc.) J. Schröt., was first reported by Butler (1907) in India and described as a disease of ill-drained lands. It is a highly destructive and widespread disease in most of the pearlmillet-growing areas of Asia and Africa (Sharma et al. 2014). The disease was considered to be a minor disease in India till 1970 due to fewer incidences on local cultivars; however, it reached epidemic levels during the mid-1970s to 1980s, when only a few single-cross hybrids were cultivated on a large scale. The first epidemic of DM occurred in 1971 on a popular pearl millet hybrid, HB 3, and resulted in severe grain loss of about 4.6 million metric tons (Singh et al. 1993). The estimated annual grain yield loss due to DM is approximately 20 to $40 \%$ but could be much higher, up to $80 \%$, under favorable conditions of high relative humidity, moderate temperature, and widespread use of the same cultivar across fields (Singh and Singh 1987; Thakur et al. 1999). Among control measures, the most important one is the use of resistant (R) cultivars, due to its high efficiency, low cost, and no harmful impact on environment (Thakur et al. 2004).

The continuous emergence of host-specific virulences in S. graminicola, due to a high degree of pathogenic variability, leads to frequent breakdown of disease resistance and poses a continuous challenges to pearl millet resistance breeding (Pushpavathi et al. 2006; Sastry et al. 2001; Thakur et al. 1992; Werder and Ball 1992). Therefore, pyramiding of resistance genes in a single genotype or identification of a single genotype with different resistance genes conferring resistance to multiple pathotypes would be the effective management strategy to increase the durability of resistance. Attempts have been made to identify several sources of resistance against one or multiple pathotypes and, based on resistance sources, several R hybrids and varieties have been released for general cultivation in India (Hash et al. 2006; Sharma et al. 2015). In addition, the inheritance of DM resistance in pearl millet has been interpreted by various workers in terms of simple and complex interactions. The DM resistance has

${ }^{\dagger}$ Corresponding author: R. Sharma; E-mail: r.sharma@cgiar.org

Accepted for publication 22 December 2017.

() 2018 The American Phytopathological Society generally been reported to be governed by a dominant gene (Appadurai et al.1975; Singh and Talukdar 1998); a recessive gene (Pethani et al. 1980; Singh et al. 1980); one, two, or more genes (Appadurai et al.1975; Gill et al.1978; Joshi and Ugale 2002); and multiple genes with epistatic effect (Deswal and Govila 1994). However, limited information on the allelic relationship among resistance genes is available. The inconsistency of gene effects over crosses could be clarified with the analysis of allelic diversity of resistance genes in pearl millet to DM and it would be more helpful in understanding that interaction between host and pathogen that will further help in the development of management strategies. Thus, in the present study, an attempt has been made to decipher the mode of inheritance of DM resistance genes and the allelic relationship between them.

\section{Materials and Methods}

Pearl millet genotypes and pathogen isolates. Seed of pearl millet genotypes were taken from genetic stocks being maintained at the International Crops Research Institute for the Semi-Arid Tropics (ICRISAT), Patancheru, India. Selected pearl millet lines were further selfed for three consecutive generations to obtain true inbreds. $S$. graminicola isolates being maintained at the Cereals Pathology Lab, ICRISAT were used to screen the pearl millet lines. The use of single-spore culture is highly recommended for inheritance and allelism studies to counter variability within pathogen populations. Hence, single-zoospore isolates Sg 526-1 (derived from pathotype Sg 526, collected from Jodhpur, Rajasthan) and Sg 542-1 (derived from pathotype $\mathrm{Sg} 542$, collected from Aurangabad, Maharashtra) were selected for greenhouse screening. These single-zoospore isolates were used to screen pearl millet lines to select $\mathrm{R}$ and susceptible (S) lines for crossing. Disease incidence (DI) was recorded 14 days after inoculation as percent infected plants. The lines with $\geq 90 \%$ DI and $\leq 10 \%$ DI were selected as S and R parents, respectively. Based on DI against Sg 526-1 and 542-1, 834 B, IP18294-P1 (a single plant selection from IP 18294), and IP18298-P1 (a single plant selection from IP 18298) were selected as R and $81 \mathrm{~B}$ as S parents to generate crosses for inheritance and allelism studies. To understand whether the same or different genes for resistance are operative in the R genotypes used in this study, test for allelism was conducted by crossing all of the R parents (834B, IP 18294-P1, and IP 18298P1) with each other. Description of the pearl millet genotypes used in this study is presented in Table 1 . 
Generation of progenies segregating for DM resistance. Staggered sowings were carried out to synchronize flowering between $S$ and $\mathrm{R}$ parents. Seedlings of both $\mathrm{R}$ and $\mathrm{S}$ parents were inoculated with the $S$. graminicola isolate and disease-free seedlings of the $\mathrm{R}$ parents were transplanted into a 25 -cm-diameter pot (4 plants/pot) and used in crossing. The $\mathrm{S}$ plants of $81 \mathrm{~B}$ were recovered by spraying Ridomyl MZ 72 WP $\left(2 \mathrm{~g} \mathrm{liter}^{-1}\right)$ and used as S parents. For inheritance studies, three $\mathrm{S} \times \mathrm{R} \mathrm{F}_{1} \mathrm{~S}(81 \mathrm{~B} \times 834 \mathrm{~B}, 81 \mathrm{~B} \times \mathrm{IP} 18294-\mathrm{P} 1$, and $81 \mathrm{~B} \times \mathrm{IP} 18298$ $\mathrm{P} 1)$ were generated. To carry out allelism test, three $\mathrm{R} \times \mathrm{R} \mathrm{F}_{1} \mathrm{~s}(834 \mathrm{~B} \times$ IP 18294-P1, 834B × IP 18298-P1, and IP 18294-P1 × IP 18298-P1) were produced in half diallel fashion without reciprocal crosses during March to June 2014. All of the crosses were made in a greenhouse. In the subsequent postrainy season during November 2014 to February 2015 , each $F_{1}$ ( 8 to 10 panicles) was selfed using parchment paper bags for the production of $F_{2}$ seed. Single-head pollen of each $F_{1}$ plant was used to pollinate the respective $S$ and $R$ parents to develop backcross populations $\mathrm{BC}_{1} \mathrm{P}_{1}\left(\mathrm{~S}\right.$ parent $\left.\times \mathrm{F}_{1}\right)$ and $\mathrm{BC}_{1} \mathrm{P}_{2}\left(\mathrm{R}\right.$ parent $\left.\times \mathrm{F}_{1}\right)$.

Inoculum preparation. The systemically infected leaves of $\mathrm{S}$ line $7042 \mathrm{~S}$ inoculated with $\mathrm{Sg} 526-1$ and $\mathrm{Sg} 542-1$ and grown in isolation chambers were collected, excised into pieces, washed under running tap water to remove old sporangia, wiped dry with tissue paper, placed by their abaxial surfaces up in humidity chambers lined with moist blotting paper, and incubated in darkness at $20^{\circ} \mathrm{C}$ for $6 \mathrm{~h}$ to induce sporulation. Sporangia of each isolate were harvested separately in ice-cold $\left(4^{\circ} \mathrm{C}\right)$ distilled sterilized water from the sporulating leaves using a soft camel-hair brush and filtered through a double-layered muslin cloth. The concentration of sporangia was measured using a hemocytometer and adjusted to $1 \times 10^{6} \mathrm{ml}^{-1}$ before inoculation.

Sowing, inoculation, and disease evaluation. For the inheritance study, seed of parents and $\mathrm{F}_{1}, \mathrm{~F}_{2}, \mathrm{BC}_{1} \mathrm{P}_{1}$, and $\mathrm{BC}_{1} \mathrm{P}_{2}$ generations of each cross were sown in 15-cm-diameter pots ( 30 to 35 seeds/pot) filled with a sterilized soil-sand-farmyard manure mix $(2: 1: 1)$ and placed in a greenhouse bay maintained at $30 \pm 2^{\circ} \mathrm{C}$. For the allelism study, seed of parents and $F_{1}$ and $F_{2}$ generations of each $R \times R$ cross were sown in plastic pots as described above for the inheritance study. The 48-h-old seedlings of parents and six $\mathrm{F}_{1}$ (three $\mathrm{S} \times \mathrm{R}$ and three $\mathrm{R} \times \mathrm{R}$ ), three $\mathrm{BC}_{1} \mathrm{P}_{1}$, three $\mathrm{BC}_{1} \mathrm{P}_{2}$, and six $\mathrm{F}_{2}$ (three $\mathrm{S} \times \mathrm{R}$ and three $\mathrm{R} \times \mathrm{R}$ ) populations were spray inoculated with an aqueous sporangial suspension (approximately $1 \times$ $10^{6} \mathrm{ml}^{-1}$ ) of two isolates ( $\mathrm{Sg} 526-1$ and $\mathrm{Sg} 542-1$ ) of S. graminicola separately using an atomizer and covered immediately with moist polyethylene sheet to provide $>90 \%$ relative humidity. Inoculated seedlings were incubated in the dark at $20^{\circ} \mathrm{C}$ for $24 \mathrm{~h}$, then transferred to greenhouse benches maintained at $25 \pm 2^{\circ} \mathrm{C}$ under mist to facilitate disease development (Thakur et al. 2011). Observations on individual seedlings were recorded at 14 days after inoculation; the plants showing DM symptoms were classified as S and healthy plants were categorized as R.

Statistical analysis. The observed ratios of $\mathrm{R}$ to $\mathrm{S}$ plants in the segregating generations $\left(\mathrm{F}_{2}\right.$ and $\left.\mathrm{BC}_{1}\right)$ in the greenhouse were compared with theoretical ratios using a $\chi^{2}$ test. The $\chi^{2}$ test $(P \leq 0.05)$ was used to test the segregation ratio of the phenotypic classes by using the program GENES (Cruz 2001).

\section{Results}

Inheritance of DM resistance. The results of inheritance studies for each cross against two isolates, Sg 526-1 and Sg 542-1, are summarized in Tables 2 and 3, respectively. The S parent $81 \mathrm{~B}$ was severely infected, showing approximately $90 \%$ DI, whereas plants of R parents
834 B and IP 18298-P1 were mostly disease free and IP 18294-P1 exhibited $<10 \% \mathrm{DM}$ incidence against both isolates. In the cross $81 \mathrm{~B} \times 834 \mathrm{~B}, 108 \mathrm{~F}_{1}$ plants, $850 \mathrm{~F}_{2}$ plants, $383 \mathrm{BC}_{1} \mathrm{P}_{1}$ (backcross with $\mathrm{S}$ parent) plants, and $416 \mathrm{BC}_{1} \mathrm{P}_{2}$ (backcross with $\mathrm{R}$ parent) plants were screened against $\mathrm{Sg} 526-1$; all of the $\mathrm{F}_{1}$ and $\mathrm{BC}_{1} \mathrm{P}_{2}$ plants exhibited resistance to $\mathrm{Sg} 526-1$, which indicated that resistance in $834 \mathrm{~B}$ to $\mathrm{Sg}$ $526-1$ is governed by dominant gene(s). In the $\mathrm{F}_{2}$ generation, 651 plants were $\mathrm{R}$ and 199 were $\mathrm{S}$, which fitted the segregation ratio of $3: 1 \mathrm{R} / \mathrm{S}$. Of $383 \mathrm{BC}_{1} \mathrm{P}_{1}$ plants, 196 were $\mathrm{R}$ whereas 187 exhibited a susceptible reaction, which indicated a $1: 1 \mathrm{R} / \mathrm{S}$ segregation ratio. Similar results were obtained for different generations of this cross when screened against $\mathrm{Sg} 542-1$; all $\mathrm{F}_{1}$ plants (106) and most of $\mathrm{BC}_{1} \mathrm{P}_{2}$ plants exhibited a resistant reaction whereas segregations were observed in $\mathrm{F}_{2}$ and $\mathrm{BC}_{1} \mathrm{P}_{1}$ plants $\left(677 \mathrm{R}\right.$ and $228 \mathrm{~S}$ plants in $\mathrm{F}_{2}$, falling in a $3: 1 \mathrm{R} / \mathrm{S}$ ratio, and $176 \mathrm{R}$ and $159 \mathrm{~S}$ plants in $\mathrm{BC}_{1} \mathrm{P}_{1}$, with a $1: 1 \mathrm{R} / \mathrm{S}$ ratio) (Table 3 ). In the second cross, $81 \mathrm{~B} \times \mathrm{IP}$ 18294-P1 screened against $\mathrm{Sg} 526-1$ (Table 2), all 120 plants of $\mathrm{F}_{1}$ generation and 357 plants of $\mathrm{BC}_{1} \mathrm{P}_{2}$ generation exhibited a resistant reaction, indicating the dominant nature of the resistance gene in IP 18294-P1 to Sg 526-1, as observed in $834 \mathrm{~B}$, whereas $\mathrm{F}_{2}$ and $\mathrm{BC}_{1} \mathrm{P}_{1}$ generations segregated into $\mathrm{R}$ (506 plants in $\mathrm{F}_{2}$ and 218 plants in $\mathrm{BC}_{1} \mathrm{P}_{1}$ ) and $\mathrm{S}\left(151\right.$ plants in $\mathrm{F}_{2}$ and 191 plants in $\mathrm{BC}_{1} \mathrm{P}_{1}$ ), with the best-fit ratio of $3: 1 \mathrm{R} / \mathrm{S}$ in $\mathrm{F}_{2}$ generation and $1: 1 \mathrm{R} / \mathrm{S}$ in $\mathrm{BC}_{1} \mathrm{P}_{1}$ generation (Table 2). Similar results were observed for this cross when screened against $\mathrm{Sg}$ 542-1 for different generations. The segregation ratios of 3:1 R/S in $F_{2}\left(558 \mathrm{R}\right.$ and $172 \mathrm{~S}$ ) and 1:1 R/S in $\mathrm{BC}_{1} \mathrm{P}_{1}$ (175 plants $\mathrm{R}$ and $148 \mathrm{~S}$ ) generations were obtained (Table 3 ). The third cross, 81B $\times$ IP 18298-P1, showed different segregation patterns in $\mathrm{F}_{2}$ and $\mathrm{BC}_{1} \mathrm{P}_{1}$ than the other two crosses. A segregation ratio of $15: 1 \mathrm{R} / \mathrm{S}$ (735 R and $52 \mathrm{~S}$ plants) in the $\mathrm{F}_{2}$ generation and 3:1 R/S (311 R and $111 \mathrm{~S}$ plants) in the $\mathrm{BC}_{1} \mathrm{P}_{1}$ generation was observed against $\mathrm{Sg}$ 526-1 (Table 2). Similar results were found when different generations of this cross were screened against $\mathrm{Sg} 542-1$; all $\mathrm{F}_{1}(122)$ and $\mathrm{BC}_{1} \mathrm{P}_{2}$ plants (287) exhibited a resistant reaction whereas segregations were observed in $\mathrm{F}_{2}$ and $\mathrm{BC}_{1} \mathrm{P}_{1}$ generations ( $823 \mathrm{R}$ and $36 \mathrm{~S}$ plants in $\mathrm{F}_{2}$ and $281 \mathrm{R}$ and $88 \mathrm{~S}$ plants in $\mathrm{BC}_{1} \mathrm{P}_{1}$ ), with the best fit ratio of $15: 1$ $\mathrm{R} / \mathrm{S}$ in $\mathrm{F}_{2}$ generation and $3: 1 \mathrm{R} / \mathrm{S}$ in $\mathrm{BC}_{1} \mathrm{P}_{1}$ generation (Table 3). The results of the DM screen indicated that resistance to $\mathrm{Sg} 526-1$ and Sg 542-1 in 834 B and IP 18294-P1 is governed by a single dominant gene, whereas two dominant genes impart resistance in IP 18298-P1 against these isolates.

Test for allelism. The results of DM screening of the $\mathrm{F}_{2}$ generation of $834 \mathrm{~B} \times \mathrm{IP}$ 18294-P1 $(\mathrm{R} \times \mathrm{R})$ against $\mathrm{Sg}$ 526-1 are presented in Table 4. In total, $690 \mathrm{~F}_{2}$ plants derived from 834B $\times$ IP 18294-P1 were screened that segregated into $640 \mathrm{R}$ and $50 \mathrm{~S}$ plants. This indicated that genes governing resistance in these two genotypes to $S$. graminicola isolate $\mathrm{Sg}$ 526-1 are different. The $\mathrm{F}_{2}$ plants derived from this cross again segregated for resistance (356 $\mathrm{R}$ and $27 \mathrm{~S}$ plants) when screened against another isolate, $\mathrm{Sg} 542-1$ (Table 5). In contrast, no segregation was observed in $\mathrm{F}_{2}$ plants derived from 834B $\times$ IP $18298-\mathrm{P} 1$ and IP $18294-\mathrm{P} 1 \times$ IP 18298-P1 crosses against both Sg 526-1 and Sg 542-1 (Tables 4 and 5), indicating an allelic relationship between genes for DM resistance in IP 18298-1 with those present in 834B and IP 18294-1. In all of the crosses, $\mathrm{F}_{1}$ plants were resistant to both isolates.

\section{Discussion}

Pearl millet is a diploid $(2 \mathrm{n}=2 \mathrm{x}=14)$ cereal crop and parent materials selected for this study were mostly homozygous inbred lines

Table 1. Description of the pearl millet genotypes used in the study ${ }^{\mathrm{a}}$

\begin{tabular}{|c|c|c|c|}
\hline Genotype & Origin & Pedigree & Special characteristics \\
\hline $834 \mathrm{~B}$ & Uganda & An S4 progeny selected from Serere 10LB & $\begin{array}{l}\text { Long bristles on spikelet, purple glumes, bold seed, loose spikelet, matures } \\
\text { early, medium height, round and dark gray seed }\end{array}$ \\
\hline IP18294 & Mali & $\ldots$ & $\begin{array}{l}\text { Zebra stripes, semicompact to compact spikelet, medium maturity, tall, } \\
\text { elliptical and brown seed }\end{array}$ \\
\hline IP18298 & Burkina Faso & $\ldots$ & $\begin{array}{l}\text { Glossy leaves, semicompact to compact spikelet, medium maturity, medium } \\
\text { height, globular and gray seed }\end{array}$ \\
\hline $81 \mathrm{~B}$ & ICRISAT, India & $\begin{array}{l}\text { Induced DM-resistant selection from Tift } \\
\text { 23DB }\end{array}$ & $\begin{array}{l}\text { Bushy at the seedling stage, compact spikelet, matures late, dwarf, obovate- } \\
\text { globular and light gray seed }\end{array}$ \\
\hline
\end{tabular}

${ }^{\mathrm{a}}$ ICRISAT $=$ International Crops Research Institute for the Semi-Arid Tropics and DM = downy mildew. 
developed after selfing for a number of generations. Maternal effect for DM resistance or susceptibility in pearl millet have been reported to be absent in earlier studies (Anand-Kumar et al. 1983; Yadav 1994, 1996; Yadav et al. 1993); thus, no reciprocal crosses were made in the present study. Resistance or susceptibility in the pearl millet-DM pathosystem is measured in absolute relative terms of percentage. Complete susceptibility or resistance in pearl millet is a rare phenomenon because both host and pathogen are highly out-crossable in nature. The presence of residual variability to the extent of 1 to $5 \%$ for resistance to DM in apparently $\mathrm{S}$ genotypes and for susceptibility up to $15 \%$ in apparently $\mathrm{R}$ genotypes has been documented (Singh and Talukdar 1998). To facilitate the selection of single-plant derivatives with complete resistance and complete susceptibility, the process of selfing and single-plant selection was followed under greenhouse conditions to reduce such hidden variability. The outcrossing nature of DM pathogen $S$. graminicola, like its host pearl millet, creates complexity in the inheritance and

Table 2. Segregation analysis for downy mildew reaction in the populations derived from susceptible $\times$ resistant $(\mathrm{S} \times \mathrm{R})$ parent crosses to Sclerospora graminicola isolate $\mathrm{Sg}$ 526-1

\begin{tabular}{|c|c|c|c|c|c|c|c|c|}
\hline \multirow[b]{2}{*}{ Cross, generations } & \multicolumn{2}{|c|}{$\begin{array}{c}\text { Number of plants } \\
\text { observed }\end{array}$} & \multirow[b]{2}{*}{ Expected ratio $^{\mathbf{a}}$} & \multicolumn{2}{|c|}{$\begin{array}{c}\text { Number of plants } \\
\text { expected }\end{array}$} & \multirow[b]{2}{*}{$\chi^{2}$} & \multirow[b]{2}{*}{$P^{\mathbf{b}}$} & \multirow[b]{2}{*}{$\mathbf{R F}^{\mathbf{c}}$} \\
\hline & $\mathbf{R}$ & $\mathbf{S}$ & & $\mathbf{R}$ & $\mathbf{S}$ & & & \\
\hline \multicolumn{9}{|l|}{$81 \mathrm{~B} \times 834 \mathrm{~B}$} \\
\hline $81 \mathrm{~B}$ & 20 & 202 & $0: 1$ & $\ldots$ & $\ldots$ & $\ldots$ & $\ldots$ & \\
\hline 834B & 204 & 2 & $1: 0$ & $\ldots$ & $\ldots$ & $\ldots$ & $\ldots$ & 1 \\
\hline $\mathrm{F}_{1}$ & 108 & 0 & $1: 0$ & $\ldots$ & $\ldots$ & $\ldots$ & $\ldots$ & \\
\hline $\mathrm{F}_{2}$ & 651 & 199 & $3: 1$ & 637.5 & 212.5 & 1.14 & 0.28 & \\
\hline $\mathrm{BC}_{1} \mathrm{P}_{1}$ & 196 & 187 & $1: 1$ & 191.5 & 191.5 & 0.21 & 0.64 & \\
\hline $\mathrm{BC}_{1} \mathrm{P}_{2}$ & 416 & 0 & $1: 0$ & $\ldots$ & $\ldots$ & $\ldots$ & $\ldots$ & \\
\hline \multicolumn{9}{|l|}{$81 \mathrm{~B} \times$ IP $18294-\mathrm{P} 1$} \\
\hline $81 \mathrm{~B}$ & 20 & 202 & $0: 1$ & $\ldots$ & $\ldots$ & $\ldots$ & $\ldots$ & \\
\hline IP 18294-P1 & 272 & 24 & $1: 0$ & $\ldots$ & $\ldots$ & $\ldots$ & $\ldots$ & 1 \\
\hline $\mathrm{F}_{1}$ & 120 & 0 & $1: 0$ & $\ldots$ & $\ldots$ & $\ldots$ & $\ldots$ & \\
\hline $\mathrm{F}_{2}$ & 506 & 151 & $3: 1$ & 492.75 & 164.25 & 1.42 & 0.23 & \\
\hline $\mathrm{BC}_{1} \mathrm{P}_{1}$ & 218 & 191 & $1: 1$ & 204.5 & 204.5 & 1.78 & 0.18 & \\
\hline $\mathrm{BC}_{1} \mathrm{P}_{2}$ & 357 & 0 & $1: 0$ & $\ldots$ & $\ldots$ & $\ldots$ & $\ldots$ & \\
\hline \multicolumn{9}{|l|}{$81 \mathrm{~B} \times \mathrm{IP} 18298-\mathrm{P} 1$} \\
\hline $81 \mathrm{~B}$ & 20 & 202 & $0: 1$ & $\ldots$ & $\ldots$ & $\ldots$ & $\ldots$ & \\
\hline IP 18298-P1 & 161 & 0 & $1: 0$ & $\ldots$ & $\ldots$ & $\ldots$ & $\ldots$ & 2 \\
\hline $\mathrm{F}_{1}$ & 140 & 0 & $1: 0$ & $\ldots$ & $\ldots$ & $\ldots$ & $\ldots$ & \\
\hline $\mathrm{F}_{2}$ & 735 & 52 & $15: 1$ & 737.81 & 49.19 & 0.17 & 0.67 & \\
\hline $\mathrm{BC}_{1} \mathrm{P}_{1}$ & 311 & 111 & $3: 1$ & 316.5 & 105.5 & 0.38 & 0.53 & \\
\hline $\mathrm{BC}_{1} \mathrm{P}_{2}$ & 371 & 0 & $1: 0$ & $\ldots$ & $\ldots$ & $\ldots$ & $\ldots$ & \\
\hline
\end{tabular}

a All possible phenotypic ratio were analyzed and the best fit are shown in the table.

${ }^{\mathrm{b}} P=$ probability; $\chi^{2}$ values are not significant at $P \leq 0.05$.

${ }^{\mathrm{c}}$ Resistance factors: number of dominant genes.

Table 3. Segregation analysis for downy mildew reaction in the populations derived from susceptible $\times$ resistant $(\mathrm{S} \times \mathrm{R})$ parent crosses to Sclerospora graminicola isolate $\mathrm{Sg} 542-1$

\begin{tabular}{|c|c|c|c|c|c|c|c|c|}
\hline \multirow[b]{2}{*}{ Cross, generations } & \multicolumn{2}{|c|}{$\begin{array}{c}\text { Number of plants } \\
\text { observed }\end{array}$} & \multirow[b]{2}{*}{ Expected ratio $^{\mathbf{a}}$} & \multicolumn{2}{|c|}{$\begin{array}{c}\text { Number of plants } \\
\text { expected }\end{array}$} & \multirow[b]{2}{*}{$x^{2}$} & \multirow[b]{2}{*}{$P^{\mathbf{b}}$} & \multirow[b]{2}{*}{$\mathbf{R F}^{\mathrm{c}}$} \\
\hline & $\bar{R}$ & $\mathbf{S}$ & & $\mathbf{R}$ & $\mathbf{S}$ & & & \\
\hline \multicolumn{9}{|l|}{$81 \mathrm{~B} \times 834 \mathrm{~B}$} \\
\hline $81 \mathrm{~B}$ & 23 & 205 & $0: 1$ & $\ldots$ & $\ldots$ & $\ldots$ & $\ldots$ & \\
\hline $834 \mathrm{~B}$ & 201 & 1 & $1: 0$ & $\ldots$ & $\ldots$ & $\ldots$ & $\ldots$ & 1 \\
\hline $\mathrm{F}_{1}$ & 106 & 0 & $1: 0$ & $\ldots$ & $\ldots$ & $\ldots$ & $\ldots$ & \\
\hline $\mathrm{F}_{2}$ & 677 & 228 & $3: 1$ & 678.75 & 226.25 & 0.018 & 0.89 & \\
\hline $\mathrm{BC}_{1} \mathrm{P}_{1}$ & 176 & 159 & $1: 1$ & 167.5 & 167.5 & 0.86 & 0.35 & \\
\hline $\mathrm{BC}_{1} \mathrm{P}_{2}$ & 366 & 19 & $1: 0$ & $\ldots$ & $\ldots$ & $\ldots$ & $\ldots$ & \\
\hline \multicolumn{9}{|l|}{$81 \mathrm{~B} \times \mathrm{IP} 18294-\mathrm{P} 1$} \\
\hline $81 \mathrm{~B}$ & 23 & 205 & $0: 1$ & $\ldots$ & $\ldots$ & $\ldots$ & $\ldots$ & \\
\hline IP 18294-P1 & 193 & 7 & $1: 0$ & $\ldots$ & $\ldots$ & $\ldots$ & $\ldots$ & 1 \\
\hline $\mathrm{F}_{1}$ & 107 & 0 & $1: 0$ & $\ldots$ & $\ldots$ & $\ldots$ & $\ldots$ & \\
\hline $\mathrm{F}_{2}$ & 558 & 172 & $3: 1$ & 547.5 & 182.5 & 0.80 & 0.37 & \\
\hline $\mathrm{BC}_{1} \mathrm{P}_{1}$ & 175 & 148 & $1: 1$ & 161.5 & 161.5 & 2.257 & 0.13 & \\
\hline $\mathrm{BC}_{1} \mathrm{P}_{2}$ & 296 & 10 & $1: 0$ & $\ldots$ & $\ldots$ & $\ldots$ & $\ldots$ & \\
\hline \multicolumn{9}{|l|}{$81 \mathrm{~B} \times$ IP $18298-\mathrm{P} 1$} \\
\hline $81 \mathrm{~B}$ & 23 & 205 & $0: 1$ & $\ldots$ & $\ldots$ & $\ldots$ & $\ldots$ & \\
\hline IP 18298-P1 & 198 & 0 & $1: 0$ & $\ldots$ & $\ldots$ & $\ldots$ & $\ldots$ & 2 \\
\hline $\mathrm{F}_{1}$ & 122 & 0 & $1: 0$ & $\ldots$ & $\ldots$ & $\ldots$ & $\ldots$ & \\
\hline $\mathrm{F}_{2}$ & 823 & 36 & $15: 1$ & 805.31 & 53.69 & 0.48 & 0.49 & \\
\hline $\mathrm{BC}_{1} \mathrm{P}_{1}$ & 281 & 88 & $3: 1$ & 276.75 & 92.25 & 0.26 & 0.61 & \\
\hline $\mathrm{BC}_{1} \mathrm{P}_{2}$ & 287 & 0 & $1: 0$ & $\ldots$ & $\ldots$ & $\ldots$ & $\ldots$ & \\
\hline
\end{tabular}

${ }^{a}$ All possible phenotypic ratio were analyzed and the best fit are shown in the table.

b $P=$ probability; $\chi^{2}$ values are not significant at $P \leq 0.05$.

${ }^{\mathrm{c}}$ Resistance factors: number of dominant genes. 
allelism study. The presence of heterothallism and different sexual compatibility types in S. graminicola further enhances the complication by generating new variability in the pathogen (Idris and Ball 1984; Michelmore et al. 1982). Sg 526 was collected from Jodhpur, Rajasthan, India in 2009 and Sg 542 was collected from Aurangabad, Maharashtra, India during 2010. Both isolates were found virulent on all nine pearl millet lines (P 7-4, P 310-17, 700651, 7042R, 852B, IP 18292, IP 18293, ICMP 451, and 7042S) of the host differential set and were selected as highly virulent pathotypes for greenhouse screening of pearl millet breeding lines bred for these ecologies.

In the present study, the $\mathrm{F}_{1}$ and $\mathrm{BC}_{1} \mathrm{P}_{2}$ plants (backcross generation with the $\mathrm{R}$ parents) of the $\mathrm{S} \times \mathrm{R}$ crosses $81 \mathrm{~B} \times 834 \mathrm{~B}, 81 \mathrm{~B} \times$ IP 18294-P1, and 81B $\times$ IP 18298-P1 were resistant to $\mathrm{Sg} 526-1$. The complete resistance in $\mathrm{F}_{1}$ and $\mathrm{BC}_{1} \mathrm{P}_{2}$ generations indicated that the resistance in these lines is governed by dominant genes. The dominant nature of resistance in pearl millet to DM has been reported earlier (Dass et al. 1984; Singh and Talukdar 1998). The R and S plants in $\mathrm{F}_{2}$ generations of the crosses $81 \mathrm{~B} \times 834 \mathrm{~B}$ and $81 \mathrm{~B} \times \mathrm{IP} 18294-\mathrm{P} 1$ showed a good fit for the segregation ratio of $3: 1 \mathrm{R} / \mathrm{S}$ to both isolates, suggesting dominant monogenic control of DM resistance in $834 \mathrm{~B}$ and IP 18294-P1. The corresponding $\mathrm{BC}_{1} \mathrm{P}_{1}$ generations had good fit for a $1: 1 \mathrm{R} / \mathrm{S}$ ratio, thus confirming the monogenic control of DM resistance in 834B and IP 18294-P1 against both isolates. The $\mathrm{F}_{2}$ generation of the cross $81 \mathrm{~B} \times \mathrm{IP} 18298-\mathrm{P} 1$ exhibited a good fit for the segregation ratio of $15: 1 \mathrm{R} / \mathrm{S}$ to both isolates, indicating the involvement of two dominant genes for resistance in IP 18298-P1. The corresponding $\mathrm{BC}_{1} \mathrm{P}_{1}$ (back cross with $\mathrm{S}$ parent) showed the 3:1 R/S ratio expected for the digenic inheritance. DM resistance has been reported to be governed by one or two genes in different inbreds of pearl millet (Appadurai et al. 1975; Singh and Talukdar 1998). The results of this study suggest monogenic resistance in 834B and IP 18494-P1 and digenic resistance in IP 18298-P1. Nevertheless, the pattern of inheritance of genes for resistance is reported to vary against different pathotypes prevalent at different locations (Deswal and Govila 1994). The inheritance of DM resistance in a single cultivar (PPMI 519) was expressed in different ratios at two locations; complementary at Delhi (9:7) and duplicate at Villupuram, Tamil Nadu (15:1) (Deswal and Govila 1994). This could be due to the differences in the reaction of genotypes against different pathotypes of $S$. graminicola present at the two locations. However, the same pattern of inheritance of DM resistance in the genotypes tested in this study was observed against pathotype-isolates collected from diverse ecologies. The results of this study indicate that these resistance genes could be used in breeding programs to develop DMresistant pearl millet cultivars for cultivation in different ecologies.

For effective disease management through host plant resistance against a highly variable pathogen such as $S$. graminicola, it is essential to understand whether resistance in different genotypes against specific pathotypes of the pathogen is governed by the same or different genes (Sharma et al. 2015). In this study, $F_{2}$ plants derived from $834 \mathrm{~B} \times \mathrm{IP} 18294-\mathrm{P} 1(\mathrm{R} \times \mathrm{R})$ showed a good fit to the segregation ratio of 15:1 R/S against both isolates, suggesting the involvement of two independent dominant resistance genes. The segregation for resistance in $\mathrm{F}_{2}$ plants derived from $834 \mathrm{~B} \times \mathrm{IP} 18294-\mathrm{P} 1$ indicated that the gene governing DM resistance in $834 \mathrm{~B}$ against $\mathrm{Sg} 526-1$ and Sg 542-1 is nonallelic to the resistance gene present in IP18294-P1. In contrast, no segregation was observed in $\mathrm{F}_{2}$ generations derived from 834B $\times$ IP 18298-P1 and IP 18294-P1 $\times$ IP $18298-\mathrm{P} 1$ crosses when screened against both isolates. This indicated an allelic relationship between genes for resistance in IP 18298-P1 with the resistance genes present in 834B and IP 18294-P1. These results further confirmed the presence of two dominant genes imparting resistance in IP 18298-P1 to $S$. graminicola because the genes for DM resistance in 834B and IP 18294-P1 were found to be different. No segregation in the $\mathrm{F}_{2}$ generation of a cross of two $R$ genotypes (PPMI 519 and PPMI 517) of pearl millet has been reported and it was inferred that the same gene for DM resistance is present in these genotypes (Deswal and Govila 1994). However, different genes for resistance in two $\mathrm{R}$ genotypes of pearl millet against the same pathotype of $S$. graminicola have not been reported thus far based on an allelism test.

The allelic relationship between resistance genes to both isolates of $S$. graminicola in this study indicated that 834B and IP 18294-P1 each contain one nonallelic dominant gene. These two dominant resistance genes could be present in IP 18298-P1 because the genes in IP 18298-P1 were found to be allelic to the different genes for DM resistance in 834B and IP 18294-P1. The designation of Rsgl has been attributed to the resistance gene identified in IP 18292 (Singh

Table 4. Test of allelism for genes governing downy mildew resistance in pearl millet lines 834B, IP18294-P1, and IP18298-P1 to Sclerospora graminicola isolate $\mathrm{Sg} 526-1$

\begin{tabular}{|c|c|c|c|c|c|c|c|c|c|}
\hline \multirow[b]{2}{*}{ Cross $^{b}$} & \multirow[b]{2}{*}{ Generation } & \multicolumn{2}{|c|}{$\begin{array}{c}\text { Number of } \\
\text { plants } \\
\text { observed }^{\mathrm{a}}\end{array}$} & \multirow[b]{2}{*}{ Expected ratio $^{c}$} & \multicolumn{2}{|c|}{$\begin{array}{c}\text { Number of plants } \\
\text { expected }^{\mathbf{a}}\end{array}$} & \multirow[b]{2}{*}{$\chi^{2}$} & \multirow[b]{2}{*}{$P^{d}$} & \multirow[b]{2}{*}{ Allelic relationship } \\
\hline & & $\mathbf{R}$ & $\bar{S}$ & & $\mathbf{R}$ & $\mathbf{S}$ & & & \\
\hline 834B × IP18294-P1 & $\mathrm{F}_{2}$ & 640 & 50 & $15: 1$ & 646.87 & 43.13 & 1.17 & 0.28 & Nonallelic \\
\hline 834B × IP18298-P1 & $\mathrm{F}_{2}$ & 866 & 0 & $\ldots$ & $\ldots$ & $\ldots$ & $\ldots$ & $\ldots$ & Allelic \\
\hline IP18294-P1 × IP18298-P1 & $\mathrm{F}_{2}$ & 687 & 0 & $\ldots$ & $\ldots$ & $\ldots$ & $\ldots$ & $\ldots$ & Allelic \\
\hline
\end{tabular}

${ }^{\mathrm{a}} \mathrm{R}=$ resistant and $\mathrm{S}=$ susceptible.

${ }^{\mathrm{b}} \mathrm{R} \times \mathrm{R}$ parent crosses.

${ }^{c}$ All possible phenotypic ratio were analyzed and the best fit is shown in the table.

d $P=$ probability; $\chi^{2}$ value is not significant at $P \leq 0.05$.

Table 5. Test of allelism for genes governing downy mildew resistance in pearl millet lines 834B, IP18294-P1 and IP18298-P1 to Sclerospora graminicola isolate Sg 542-1

\begin{tabular}{|c|c|c|c|c|c|c|c|c|c|}
\hline \multirow[b]{2}{*}{ Cross $^{b}$} & \multirow[b]{2}{*}{ Generation } & \multicolumn{2}{|c|}{$\begin{array}{c}\text { Number of } \\
\text { plants } \\
\text { observed }^{\mathbf{a}}\end{array}$} & \multirow[b]{2}{*}{ Expected ratio ${ }^{c}$} & \multicolumn{2}{|c|}{$\begin{array}{c}\text { Number of plants } \\
\text { expected }^{\mathrm{a}}\end{array}$} & \multirow[b]{2}{*}{$\chi^{2}$} & \multirow[b]{2}{*}{$P^{\mathrm{d}}$} & \multirow[b]{2}{*}{ Allelic relationship } \\
\hline & & $\mathbf{R}$ & $\overline{\mathrm{S}}$ & & $\mathbf{R}$ & $\mathbf{S}$ & & & \\
\hline 834B $\times$ IP18294-P1 & $\mathrm{F}_{2}$ & 356 & 27 & $15: 1$ & 359.06 & 23.94 & 0.42 & 0.52 & Nonallelic \\
\hline 834B $\times$ IP18298-P1 & $\mathrm{F}_{2}$ & 913 & 0 & $\ldots$ & $\ldots$ & $\ldots$ & $\ldots$ & $\ldots$ & Allelic \\
\hline IP18294-P1 × IP18298-P1 & $\mathrm{F}_{2}$ & 729 & 0 & $\ldots$ & $\ldots$ & $\ldots$ & $\ldots$ & $\ldots$ & Allelic \\
\hline
\end{tabular}

${ }^{a} \mathrm{R}=$ resistant and $\mathrm{S}=$ susceptible.

${ }^{\mathrm{b}} \mathrm{R} \times \mathrm{R}$ parent crosses.

c All possible phenotypic ratio were analyzed and the best fit is shown in the table.

${ }^{\mathrm{d}} P=$ probability; $\chi^{2}$ value is not significant at $P \leq 0.05$. 
and Talukdar 1998). However, to confirm the relationship between resistance genes in 834B and IP 18294-P1 with that of IP 18292 $(R S g 1)$, there is a need to conduct a test for allelism for the gene governing resistance in IP 18292 with the DM resistance genes present in $834 \mathrm{~B}$ and IP 18294-P1 by screening against the same pathotype. Nevertheless, there is a possibility of having more DM resistance genes in these lines that could be revealed by involving more $\mathrm{R}$ lines in the crossing program and screening with a greater number of diverse DM pathotypes. Because the lines used in this study (IP 18294-P1, IP 18298-P1, and 834B) originated from three different countries (Mali, Burkina Faso, and Uganda, respectively), the geographical diversity of these lines could represent diversity for the resistance genes as well (Caicedo 2008). Therefore, use of resistance sources of diverse origin, with the probable different genes for resistance, in the breeding programs can help diversify and broaden the genetic base for DM resistance in pearl millet to cope up with the evolving virulences in the pathogen.

Pearl millet breeding at ICRISAT, Patancheru, India has been focused on developing and disseminating a diverse range of highyielding, DM-resistant, trait-based breeding lines and hybrid parents (seed parents and restorer parents) for utilization in hybrid development and commercialization by the National Agricultural Research System and private seed companies (Rai et al. 2014). The large onfarm hybrid cultivar diversity has not only led to the increased grain productivity but also stemmed the large-scale DM epidemics that were frequent events prior to 1990 (Rai et al. 2006). The results of the present study have important implications for breeding programs which aim to deploy DM resistance genes or stack different genes conferring resistance to different pathotypes of DM into elite cultivars. According to Thakur et al. (2008), pyramiding of genes is a strategy to develop varieties with durable DM resistance in pearl millet. The stacking of resistance genes with major effects delays the appearance of new races of the pathogen. The basis for this stability of resistance is the decrease in pathogen fitness when a number of virulence genes are necessary to overcome the resistance of the host (Van der Plank 1984). Therefore, a potential strategy in order to maintain disease resistance for a long period of time would be the introgression of several resistance genes in a single variety. The data obtained in the present study demonstrate that the breeder should choose a number of sources having different resistance genes for gene pyramiding, in order to put together in the best possible combination of genes in new cultivars. Therefore, these varieties expressing durable resistance would be resistant to a large number of pathotypes of the pathogen over a long period of time. However, more studies are required to identify different resistance genes (nonallelic) for their spatial and temporal deployment.

\section{Literature Cited}

Anand Kumar, K., Jain, R. P., and Singh, S. D. 1983. Downy mildew reactions in pearl millet lines with and without cytoplasmic male sterility. Plant Dis. 67:663-665.

Appadurai, R., Parambaramani, C., and Natrajan, U. S. 1975. Note on the inheritance of susceptibility of pearl millet to downy mildew. Indian J. Agric. Sci. 45:179-180

Butler, E. J. 1907. Some diseases of cereals caused by Sclerospora graminicola. Mem. Dep. Agric. India Bot. 2:1-24.

Caicedo, A. L. 2008. Geographic diversity cline of $R$ gene homologs in wild populations of Solanum pimpinellifolium (Solanaceae). Am. J. Bot. 95:393-398.

Cruz, C. D. 2001. GENES programme-Windows version. Computer Application in Genetics and Statistics, 1st ed. Editora UFV, Viçosa, MG, Brazil.

Dass, S., Kapoor, R. L., Paroda, R. S., and Jatsara, D. S. 1984. Gene effects for downy mildew (Sclerospora graminicola) resistance in pearl millet. Indian J. Genet. Plant Breed. 44:280-285.

Deswal, D. P., and Govila, O. P. 1994. Genetics of disease resistance to downy mildew (Sclerospora graminicola) in pearl millet (Pennisetum glaucum (L.) R. Br.). Indian J. Agric. Sci. 64:661-663.

Gill, K. S., Phul, P. S., Chahal, S. S., and Singh, N. B. 1978. Inheritance of resistance of downy mildew disease in pearl millet. Cereal Res. Commun. 6:71-74.
Hash, C. T., Thakur, R. P., Rao, V. P., and Bhaskar, R. A. G. 2006. Evidence for enhanced resistance to diverse isolates of pearl millet downy mildew through gene pyramiding. Int. Sorghum Millets Newsl. 47:134-138.

Idris, M. O., and Ball, S. L. 1984. Inter- and intracontinental sexual compatibility in Sclerospora graminicola. Plant Pathol. 33:219-223.

Joshi, V. J., and Ugale, S. D. 2002. Involvement of higher order interactions addressing complex polygenetically controlled inheritance of downy mildew [Sclerospora graminicola (Sacc.) Schrot] resistance in pearl millet [Pennisetum glaucum (L.) R. Br.]. Euphytica 127:149-161.

Michelmore, R. W., Pawar, M. N., and Williams, R. J. 1982. Heterothallism in Sclerospora graminicola. Phytopathology 72:1368-1372.

Pethani, K. V., Kapoor, R. L., and Chandra, S. 1980. Gene action and phenotypic stability for incidence of downy mildew disease in pearl millet. Indian J. Agric. Res. 14:217-223.

Pushpavathi, B., Thakur, R. P., Chandrashekara, R. K., and Rao, V. P. 2006 Characterization of Sclerospora graminicola isolates from pearl millet for virulence and genetic diversity. Plant Pathol. J. 22:28-35.

Rai, K. N., Gupta, S. K., Sharma, R., Govindaraj, M., Rao, A. S., Shivade, H., and Bonamigo, L. A. 2014. Pearl millet breeding lines developed at ICRISAT: A reservoir of variability and useful source of non-target traits. SAT eJournal 12:1-13.

Rai, K. N., Kulkarni, V. N., Thakur, R. P., Haussmann, B. I. G., and Mgonja, M. A 2006. Pearl millet hybrid parents research: Approaches and achievements. Pages 11-74 in: Hybrid Parents Research at ICRISAT. C. L. L. Gowda, K. N. Rai, B. V. S. Reddy, and K. B. Saxena, eds. International Crops Research Institute for the Semi-Arid Tropics, Patancheru, Andhra Pradesh, India.

Sastry, J. G., Sivaramakrishnan, S., Rao, V. P., Thakur, R. P., Singru, R. S., Gupta, V. S., and Ranjekar, P. K. 2001. Genetic basis of host specificity in Sclerospora graminicola, the pearl millet downy mildew pathogen. Indian Phytopathol. 54: 323-328.

Sharma, R., Gupta, S. K., Kadvani, D. L., Shivpuri, A., and Rai, K. N. 2014. New virulent pathotypes of Sclerospora graminicola and resistance sources in pearl millet for A1 zone in India. Indian J. Agric. Sci. 84:707-710.

Sharma, R., Upadhyaya, H. D., Sharma, S., Gate, V. L., and Raj, C. 2015. New sources of resistance to multiple pathotypes of Sclerospora graminicola in the pearl millet mini core germplasm collection. Crop Sci. 55:1619-1628.

Singh, F., Singh, R. M., Singh, R. B., and Singh, R. K. 1980. Genetic studies of downy mildew resistance in pearl millet. Pages 171-172 in: Trends in Genetic Research of Pennisetum species. V. P. Gupta and J. L. Minocha, eds. Wesley Press, Ludhiana, India.

Singh, S. D., King, S. B., and Werder, J. 1993. Downy mildew disease of pearl millet. Inf. Bull. No. 37. International Crops Research Institute for the SemiArid Tropics, Patancheru, Andhra Pradesh, India.

Singh, S. D., and Singh, G. 1987. Resistance to pearl millet hybrid NBH 3. Indian Phytopathol. 40:178-180.

Singh, S. D., and Talukdar, B. S. 1998. Inheritance of complete resistance to pearl millet downy mildew. Plant Dis. 82:791-793.

Thakur, R. P., Rai, K. N., Khairwal, I. S., and Mahala, R. S. 2008. Strategy for downy mildew resistance breeding in pearl millet in India. J. SAT Agric Res. 6:1-11.

Thakur, R. P., Rao, V. P., Sastry, J. G., Sivaramakrishnan, S., Amruthesh, K. N., and Barbind, L. D. 1999. Evidence for a new virulent pathotype of Sclerospora graminicola on pearl millet. J. Mycol. Plant Pathol. 29:61-69.

Thakur, R. P., Rao, V. P., Wu, B. M., Subbarao, K. V., Shetty, H. S., Singh, G., Lukose, C., Panwar, M. S., Sereme, P., Hess, D. E., Gupta, S. C., Dattar, V. V., Panicker, S., Pawar, N. B., Bhangale, G. T., and Panchbhai, S. D. 2004. Host resistance stability to downy mildew in pearl millet and pathogenic variability in Sclerospora graminicola. Crop Prot. 23:901-908.

Thakur, R. P., Sharma, R., and Rao, V. P. 2011. Screening techniques for pearl millet diseases. Inf. Bull. No. 89. International Crops Research Institute for the Semi-Arid Tropics, Patancheru, Andhra Pradesh, India.

Thakur, R. P., Shetty, K. G., and King, S. B. 1992. Selection for host-specific virulence in asexual populations of Sclerospora graminicola. Plant Pathol 41:626-632.

Van der Plank, J. E. 1984. Disease Resistance in Plants. Academic Press, New York.

Werder, J., and Ball, S. L. 1992. Variability of pearl millet downy mildew (Sclerospora graminicola) and its implication for breeding for stable and durable resistance. Trop. Pest Manage. 38:43-47.

Yadav, O. P. 1994. Influence of $A_{1}$ cytoplasm in pearl millet: A review. Plant Breed. Abstr. 64:1375-1379.

Yadav, O. P. 1996. Downy mildew incidence of pearl millet hybrids with different male sterility inducing cytoplasms. Theor. Appl. Genet. 92:278-280.

Yadav, O. P., Manga, V. K., and Gupta, G. K. 1993. Influence of $A_{1}$ cytoplasmic substitution on downy mildew incidence in pearl millet. Theor. Appl. Genet. 87: 558-560. 